University of South Florida

DIGITAL COMMONS

Digital Commons @ University of

@ UNIVERSITY OF SOUTH FLORIDA

South Florida

Early Visions Bucket

Early Visions of Florida

1867-01-01

\title{
Slave Songs of the United States
}

William Francis Allen

Lucy McKim Garrison

Charles Pickard Ware

Follow this and additional works at: https://digitalcommons.usf.edu/early_visions_bucket

\section{Recommended Citation}

Allen, William Francis; McKim Garrison, Lucy; and Ware, Charles Pickard, "Slave Songs of the United States" (1867). Early Visions Bucket. 43.

https://digitalcommons.usf.edu/early_visions_bucket/43

This Article is brought to you for free and open access by the Early Visions of Florida at Digital Commons @ University of South Florida. It has been accepted for inclusion in Early Visions Bucket by an authorized administrator of Digital Commons @ University of South Florida. For more information, please contact digitalcommons@usf.edu. 


\section{Early Visions of Florida}

Poetry • Stories • Chronicles from an American Borderland

\section{Slave Songs of the United States}

Slave Songs of the United States (1867) is widely considered the first published anthology of Negro (African American) Spirituals recorded. These songs document, mourn and celebrate the language, pain, hope and resilience of a people who were brought here forcefully, treated inhumanely, converted to a foreign religion, fought for freedom, and who eventually were released from physical bondage with the Emancipation Proclamation of 1863. Singing was a way of daily life for Africans - permeating daily activities, tied to ritual and traditional religion.

The first enslaved Africans were brought to Florida by Spain during the sixteenth century, before Britain gained control of the region, as Spain was looking to colonize the Americas. As the British gained control of Florida, large slave-run plantations became prolific. As the plantation system spread, the British imposed slavery in Florida, and "antebellum slavery," became an economic and social staple. The harsh conditions motivated many slaves to flee to southern parts of Florida where the marsh and swamp were difficult to navigate, making it easier to disappear.

African religion was forbidden on the plantation and many slaves converted, at least partially, to Christianity. Within Africanized Christianity spirituals allowed the community to give voice to its faith, hopes and sorrows. Some songs were delivered low and drawn out, to portray struggle and suffering. These are referred to as "sorrow songs." Themes of sadness, disappointment about their station in life and a pleading for freedom can be found throughout. These hymns were often sung as call and response, with one main singer relaying a line, sometimes improvised, followed by a repetition of the same line by the others gathered.

In 1861 during the Civil War, Union forces in the first joint land and sea attack, seized control of the Port Royal Sound in South Carolina. White plantation owners and confederate supporters fled the area, leaving behind homes, businesses, land, and over ten thousand slaves. The Union army considered these Africans as contrabands of war: neither free nor enslaved. Acknowledging that his soldiers would not be able to successfully ward of an attack should the Confederates return, Colonel Thomas Wentworth Higginson issued a decree freeing any slave that came to the area from other parts of South Carolina and Florida to fight on behalf of the North. Thousands migrated to the area. In 1862 Gideon missionaries (who were businessmen, educators and other 
professionals) arrived in the area, building schools and hospitals. While in Port Royal, South Carolina and part of the Port Royal Experiment, Gideonites Lucy McKim Garrison, William Francis Allen, and Charles Pickard Ware learned and documented songs they heard from the formerly enslaved Africans living on the islands. There, they compiled over one hundred "slave" songs from throughout the South and Gulf states.

The first slave songs documented were by Lucy McKim prior to the Port Royal Experiment, the popular "Roll Jordan Roll," sung throughout South Carolina (and assumed to have traveled as far south as Florida) and "Poor Rosy Gal." These two songs paved the way for a published collection. Of the 136 songs transcribed in Slave Songs of the United States, at least six can be documented to be from Florida: "My Father, How Long?, "I'm in Trouble," "O Daniel," "O Brother, Don't Get Weary," "I Want to Join the Band," and "Jacob's Ladder." These six are included below, with performances followed by transcriptions and page images.

Edited by Mahisa Henry, University of South Florida St. Petersburg

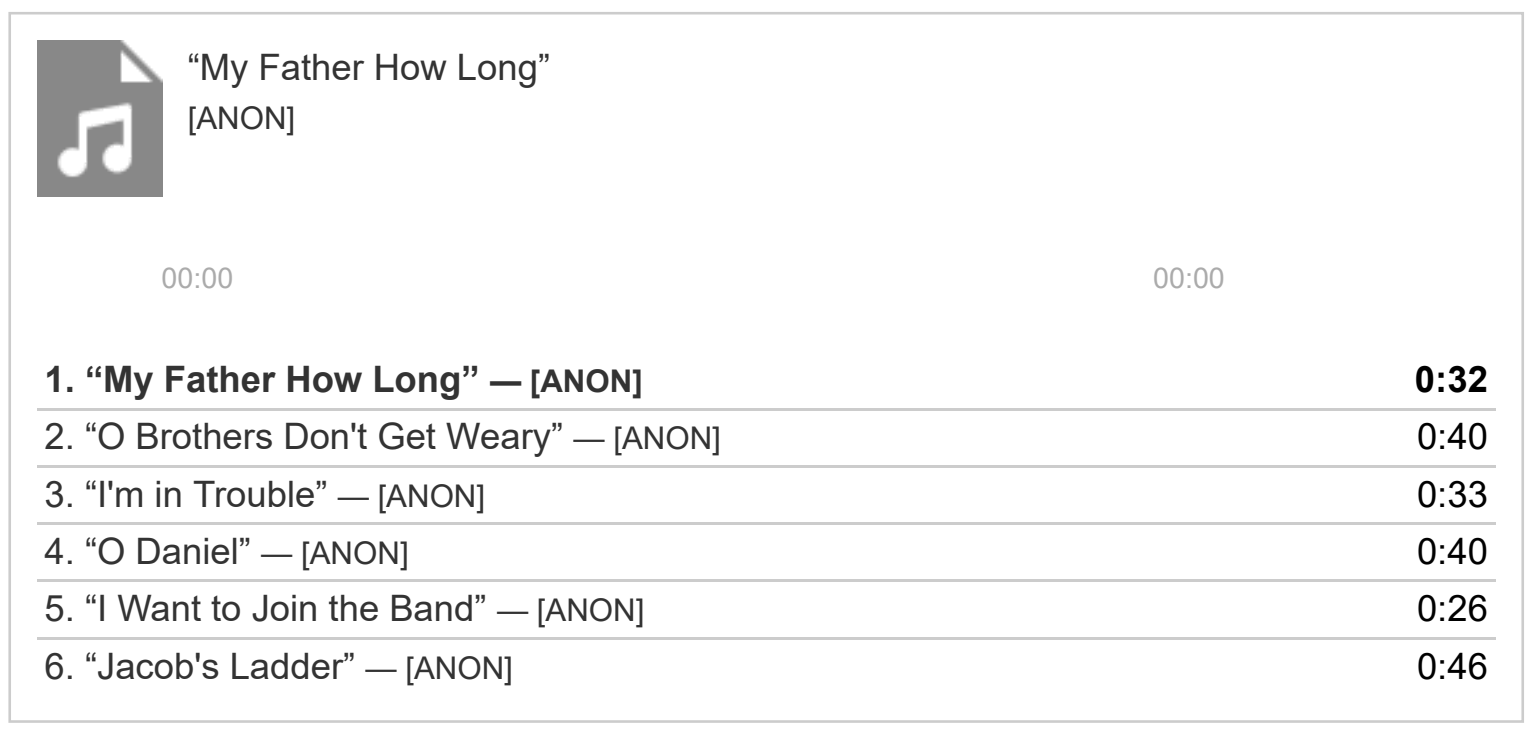

\section{Further Reading}

Simms, David McD. "The Negro Spiritual: Origins and Themes." The Journal of Negro Education 35:1 (1966): 35-41.

Higginson, Thomas Wentworth. Army Life in a Black Regiment. Boston: Fields, Osgood, 1970.

White, John. "Veiled Testimony: Negro Spirituals and the Slave Experience." Journal of American Studies 17:2 (1983): 251-263.

Williams, Edwin L. Jr. "Negro Slavery in Florida." The Florida Historical Quarterly 28:2 (1949): 93110. 
Allen, William Francis, Lucy McKim Garrison and Charles Pickard Ware. Slave Songs of the United States. New York: A. Simpson, 1867.

My Father, How Long?

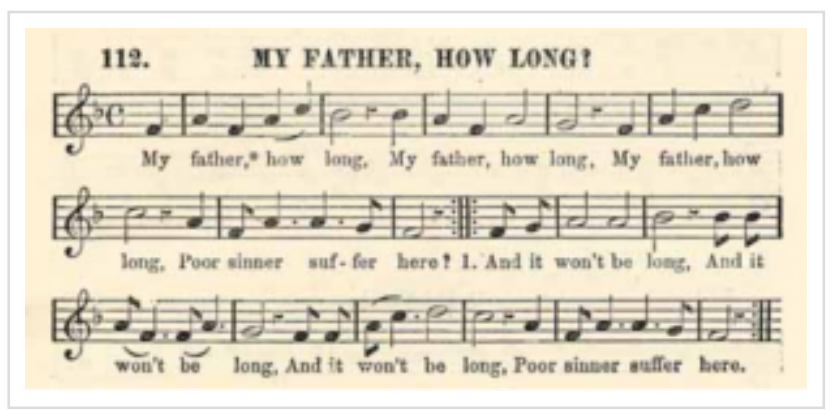

My father, how long?

My father, how long?

My father, how long?

Poor sinner suffer here?

And it won't be long,

And it won't be long,

And it won't be long,

Poor sinner suffer here.

[verse 2] We'll soon be free, (ter)

De Lord will call us home

3 We'll walk the wiry road

Where pleasure never dies

4 We'll walk the golden streets

of de New Jerusalem

5 My brudders do sing

de praises of the Lord 
When de Lord will call us home

$\underline{\text { I'm in Trouble }}$

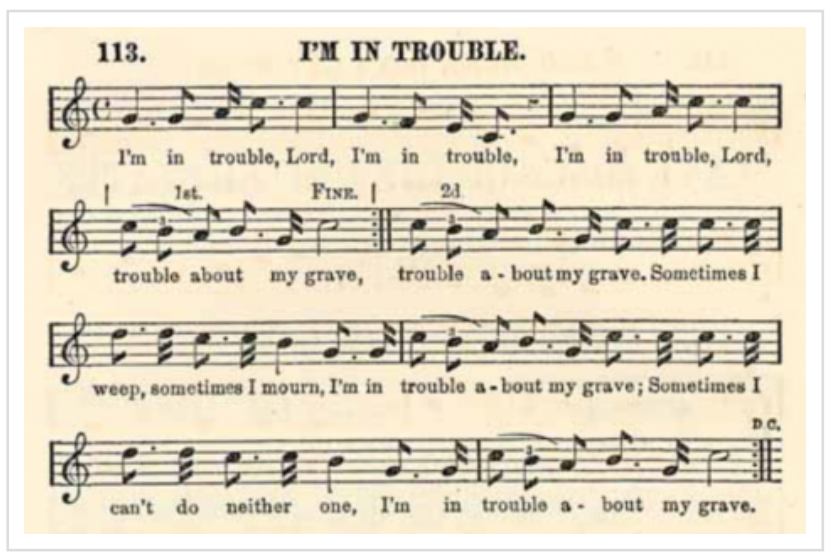

I'm in trouble, Lord,

I'm in trouble,

I'm in trouble, Lord

Trouble about my grave,

Trouble about my grave.

Sometimes I weep,

Sometimes I mourn,

I'm in trouble about my grave;

Sometimes I can't do neither one

I'm in trouble about my grave.

O Daniel 


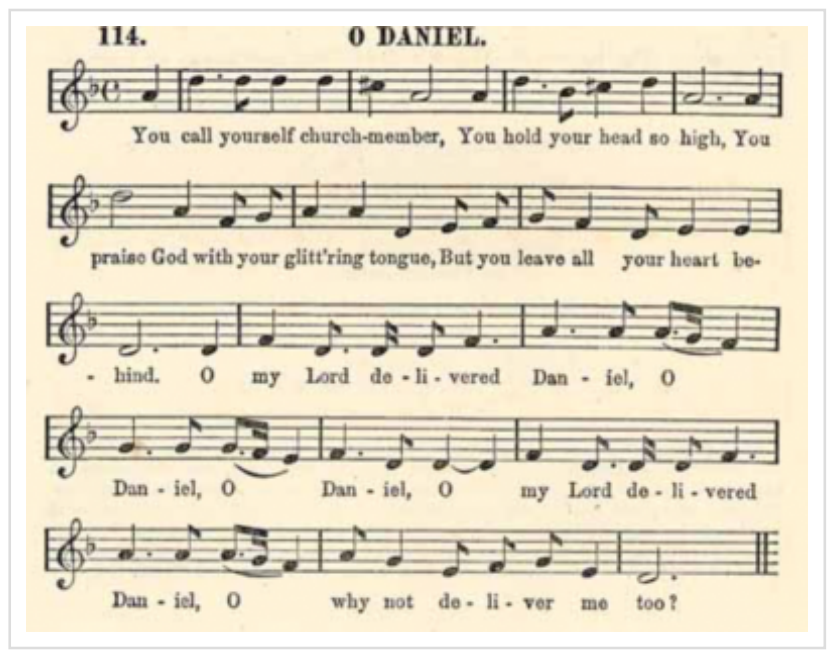

You call yourself church member

You hold your head up high

You praise God with your glitt'ring tongue

But you leave all your heart behind.

O my Lord delivered Daniel

O Daniel, O Daniel

O my Lord delivered Daniel,

O why not deliver me too?

\section{O Brothers Don't Get Weary.}

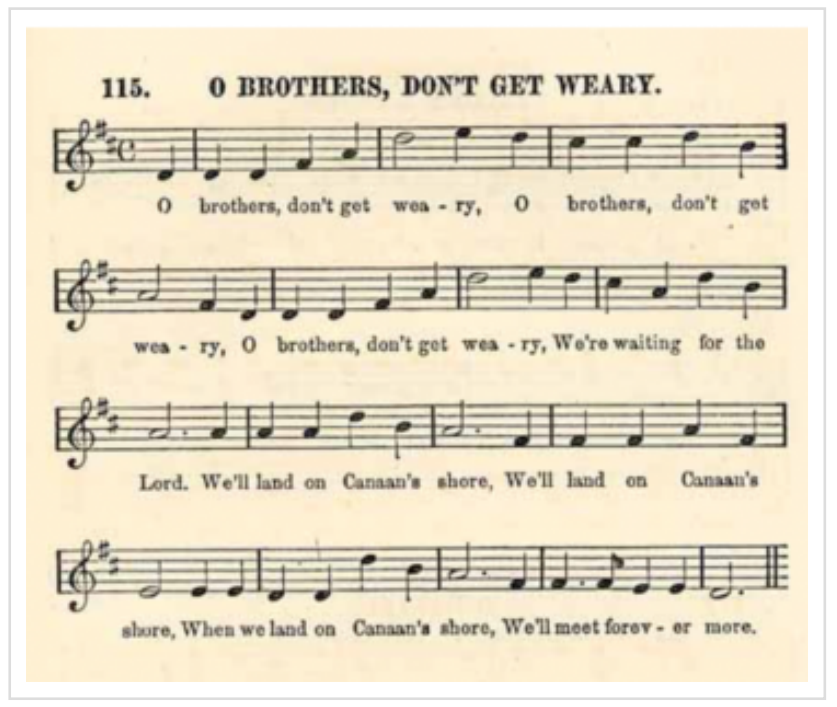


O brothers don't get weary

O brothers don't get weary

O brothers don't get weary

We're waiting for the Lord.

We'll land on Canaan's shore.

We'll land on Canaan's shore.

When we land on Canaan's shore,

We'll meet forever more.

\section{Want to Join the Band}

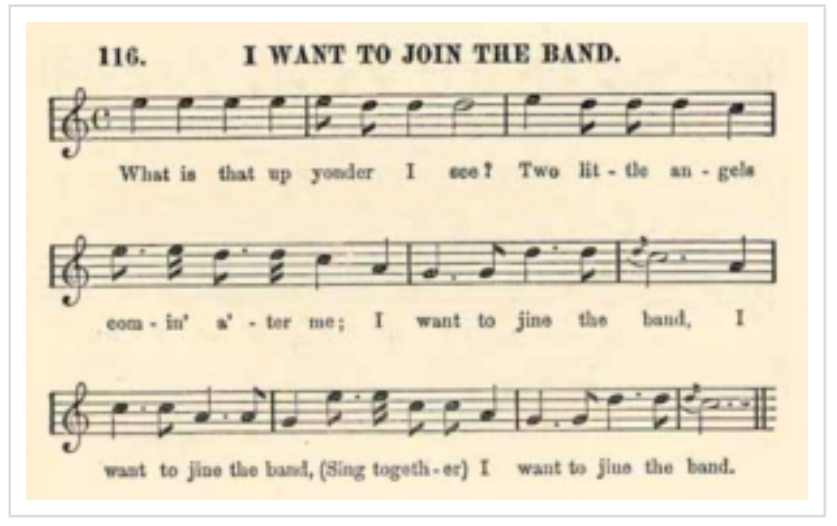

What is up yonder I see?

Two little angels comin' a'ter me.

I want to jine the band.

I want to jine the band.

(Sing together) I want to jine the band.

Jacob's Ladder 


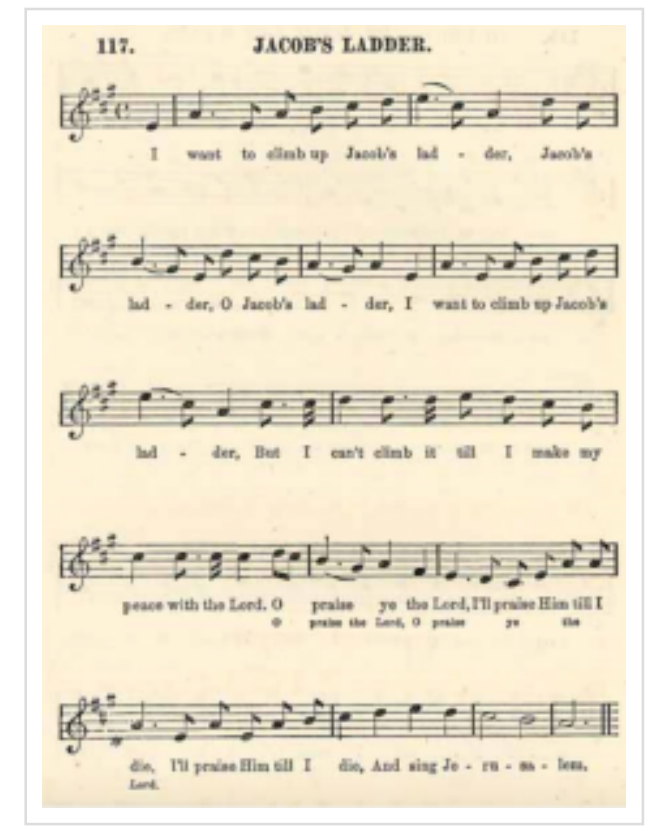

I want to climb up Jacob's ladder

Jacob's ladder

O Jacob's ladder

I want to climb up Jacob's ladder

But I can't climb it till I make my peace with the Lord.

O praise ye Lord,

I'll praise him till I die,

I'll praise him till I die

And sing Jerusalem. 